International Journal of Economics, Business and Accounting Research (IJEBAR)

Peer Reviewed - International Journal

Vol-3, Issue-2, 2019 (IJEBAR)

ISSN: 2454-1362, http://www.jurnal.stie-aas/ijebar

\title{
STRATEGIC MANAGEMENT OF EDUCATION TO ENHANCE ENVIRONMENTAL-ORIENTED COMPETITIVENESS ON INDUSTRIAL 4.0
}

\author{
Juni Iswanto, Amiartuti Kusmaningtyas, Murgianto \\ Universitas 17 Agustus 1945 Surabaya \\ Email :juni.iswanto@gmail.com
}

\begin{abstract}
This research is motivated by the strategy carried out by the management including collaborating with alumni to promote their alma mater in new prospective students in their neighborhoods and workplaces. This strategy is considered to be able to increase competitiveness, by building a culture of scientific excellence that makes quality and tough students face the challenges of the times. This research uses a qualitative approach. Data collection techniques are in-depth interviews, observation, Focus Group Discussion, and documentation. Data analysis techniques used in this study are data reduction, data presentation, and drawing conclusions / verification. From the results of this study, the researcher concludes that: competitive strategies are carried out by: a) an increasingly greater demand for good communication with the foundation for the advancement of madrasas, increasing education staff and infrastructure, b) Offers to outsiders by preparing and managing students well, integrating Learning from the curriculum of the Ministry of religion and the salafiyah curriculum. c) Marketing by combining learning of the Ministry of religion curriculum and the Salafiyah curriculum, costs allocated according to the budget, alumni become real live brochures, using the website and having a marching competition, access to madrasas is very easy, and location expansion. Based on internal and external analysis above, the institution is in a stable growth strategy which means that the situation is favorable because boarding schools have opportunities and strengths, boarding schools can take full advantage of opportunities so as to be able to implement strategies that support aggressive growth policies.
\end{abstract}

Keywords: Strategic Management, Competitiveness

\section{INTRODUCTION}

The dynamics of community life really need madrasa, madrasa experiencing changes and developments regarding its management. Today not a few boarding schools in Indonesia have adopted a formal education system such as that held by the Indonesian government. In general, formal education established in Islamic boarding schools is still in the path of Islamic education, namely Madrasah Diniyah (Madin), Madrasah Ibtidaiyah (MI),
Madrasah Tsanawiyah (MTs), and Madrasah Aliyah (MA) to higher education (Rahim, 2001) .

Considering the process of change that has taken place in Islamic boarding schools, it appears that to this day the institution has made an important contribution in the administration of national education. The existence of Islamic boarding schools as educational institutions, both those that still maintain traditional education systems and those that have undergone changes, have a profound influence on the lives of 
Indonesian people. From time to time, the existence of madrasas is growing and developing both in quantity and quality. Not a few people who pay attention and hopes for the madrasa as an alternative education. Moreover, with various innovations in the education system developed in madrassas by adopting a general education style, madrasas are increasingly competitive in offering education to the public. Despite having made various educational innovations, to date madrasa education has not lost its unique characteristics that distinguish itself from the general education model that is formulated in the form of formal education.

One of the boarding schools capable of gradually re-actualizing is the Islamic Boarding School under the auspices of the Al-Ghozali Foundation or named MiftahulMubtadiin Islamic Boarding School or better known as "PondokKrempyang" which was established by KH. Moh. Ghozali Manan. After he died, precisely on Monday, 24 RobiusTsani 1411 H / 12 December 1990 AD, MiftahulMubtadiin Islamic Boarding School was raised by his sons, KH. Moh. RidlwanSyaibani and KH. Moh. HamamGhozali. In this period, the development of Islamic boarding schools appeared to be increasingly rapid and progressed quite significantly, the existing education units still exist and even developed rapidly.

The high demand for the Madrasah Tsanawiyah can be caused by several factors, including the different supply patterns of the price or budget required. Madrasah Tsanawiyah from the Al-Ghozali Foundation Islamic boarding school in offering products and / or services through several activities, including: first, conducting visits or direct socialization to students in some public and private elementary and MI primary schools in Nganjuk through an alumni network, secondly, through the provision of various competitions by inviting or bringing in participants from every elementary and MI school, both public and private in Nganjuk Regency. Third, collaborate with alumni to promote their alma mater in prospective new students in their neighborhoods and workplaces. With the strategy carried out by administrators of the Madrasah Tsanawiyah from the $\mathrm{Al}$ Ghozali Islamic boarding school, it is hoped that it can improve competitiveness in the Industrial Age 4.0. With this endeavor to build a superiorscientific culture that produces quality and resilient students who face the challenges of the times.

The phenomenon experienced by Madrasah Tsanawiyah Al-Ghozali Foundation Islamic Boarding School is in line with the concepts in the theory of demand and supply. Mankiw (2004) explains that demand in general is the demand for an item or service, which is not only influenced by the goods themselves, but is also influenced by the prices of other related goods, consumer incomes, population and number of requests in the previous year. Mankiw Offer (2004), states that the quantity (quantity supplied) of an item or service is the amount of goods that are willing and able to be sold by the seller. There are many things that determine the amount of supply of goods, but when we analyze how the market works, one of the determinants is the price of the goods.

The uniqueness of MTs at the AlGhozali Foundation Islamic boarding school, Nganjuk Regency, which combines the following things as well as its competitive strategy: 1) becomes the center of strengthening and developing scientific, Islamic, and nationalist perspectives within the framework of aqidahahl al sunnah wa al pilgrims imbued with morals al karimah. 2) Madrasah Diniyah MTs Darussalam Program is a salafiyah-based educational activity program that must be followed by 
all MTs Students in the Ministry of Religion Curriculum. 3) Supporting the development of Lifeskill and Achievement by providing qiro'atulqur'an training, khitobah every month, computer courses, bahtsulmasail, tahfidz al-Qur'an, coaching programs, and developing achievement of special subjects and programs.

Educational institutions are actually non-profit organizations that provide services to the community who use education in the years to come, the educational climate is no longer like the past. The atmosphere has begun to be felt, with a business approach, education is slowly moving to a competitive market mechanism. In this market competition map, the winners will be those who are able to be efficient, effective, serve well, have quality, and are market-oriented. Therefore, it is fitting that the management of educational institutions must change through better management and management. If so, then the importance of building an image is very important. While the best approach in building image is through marketing. Therefore, marketing for educational institutions today is very important.

Based on the above background explanation, the authors are interested in conducting research under the title "Strategic Management of Education in Improving Environmental Oriented Competitiveness in the Industrial Age 4.0 (Study at the Al GhozaliNganjuk Islamic Foundation)".

Based on the background given above, the formulation of the problem presented is: "What is the model for developing a competitive Madrasah Tsanawiyah (MTs) strategy from the Al Ghozali Foundation Islamic Boarding School, Nganjuk Regency?"

\section{RESEARCH METHODS Research Design}

According to Sugiyono (2014: 9) qualitative research method is a method based on the philosophy of post-positivism, used to examine natural conditions of objects, (as opposed to experiments) where researchers are as key instruments, data collection techniques are carried out by triangulation (combined), data analysis is inductive / qualitative, and qualitative research results emphasize more on meaning than generalization. Basically, a qualitative approach involves the conceptualization process and results in the formation of classification schemes (Silalahi, 2009).

Research with a qualitative approach emphasizes the analysis of the process of thought processes inductively related to the dynamics of the relationship between observed phenomena, and always using scientific logic. Qualitative research is meaningless without using support from quantitative data, but rather emphasizes the depth of formal thinking of researchers in answering the problems they face. Qualitative research aims to develop the concept of sensitivity to the problem at hand, explain the reality associated with the search for theories from below (grounded theory) and develop an understanding of one or more of the phenomena encountered. Qualitative research is a research method used in expressing problems in the working lives of government, private, social, youth, women's, sports, arts and cultural organizations, so that it can be used as a policy to be implemented for the common welfare.

In order to obtain a qualitative conception in this research, the researchers conducted a study of the things around the object under study, both directly related or not directly related to the object under study. Researchers will try to express and explain everything related to the object to be examined in the actual conditions.

\section{Method Of Collecting Data}

In conducting data collection, researchers used several alternatives in the 
form of ways, for further analysis. This, as explained by Bungin (2008) which classifies the procedure or method referred to in three forms, including:

\section{1) Observation}

Is a data collection technique used to collect research data, research data can be observed by researchers? Observations in this study use direct observation, the meaning of direct observation is observation made directly on the object being observed. This study uses observation techniques to be able to gain an in-depth understanding of the object of research.

To obtain depth in observation researchers conducted observations in the madrasa environment from morning activities to students going home. In this case researchers were fully involved in observations related to learning activities from the beginning to the end of learning. As for the observed environment is the physical environment, social economic environment and cultural, work environment, human environment.

2) In-depth interview (indepth interview)

Interview is a process of obtaining information for research purposes by means of question and answer by face to face between the interviewer and the respondent or interviewee, with or without using interview guides. In conducting in-depth interviews by exploring information related to internal and external strategies conducted by Madrasah Tsanawiyah (MTs) in the Al Ghozali Foundation Islamic Boarding School in Nganjuk Regency.

The determination of research informants is based on the results of considerations in the analysis of position, reputation and decisions. Position analysis is determined to look for individuals who have positions and positions that are important in providing key information needed in research, so it can be expected that the information provided will be useful according to what is needed in the formulation of the problem and research focus Parties informants involved in the interview include : Foundation administrators, madrasa committee, teachers, badal teachers, non-educational staff and guardians of students in Tsanawiyah Madrasah (MTs) in the Al Ghozali Foundation Islamic Boarding School in Nganjuk Regency.

\section{3) Focus Group Discussion (FGD)}

The FGD aims to collect data on participants' perceptions and views on something, not trying to find consensus or make decisions about what actions will be taken. Therefore, open ended questions are used in the FGD, which allows participants to provide answers accompanied by explanations.In this case the researchers will do include:

a. Set up a strategy for implementing the FGD between the Head of Madrasah with the Foundation and employees and the Head of Madrasah.

b. Establish topics that will be discussed include internal and external strategies

c. Making FGD policy guidelines including ethics, rules, procedures, and steps for implementing the FGD

\section{4) Documentation}

Data collection techniques with the method of documentation is the search for data in the form of notes, transcripts, books, newspapers, magazines, inscriptions, minutes of meetings, agendas and others related to research. In qualitative and descriptive research, data is collected through photographs, documents related to the research topic, or researchers' field notes at the time the research is conducted.

Data that will be explored by researchers include Infrastructure, Teachers, 


\section{Vol-3, Issue-2, 2019 (IJEBAR)}

ISSN: 2454-1362, http://www.jurnal.stie-aas/ijebar

Student data, non-educational personnel and madrasa facilities

\section{Data Analysis Technique}

1) Descriptive Analysis

Data analysis is the process of systematically searching for and compiling data obtained from interviews, field notes, and documentation, by organizing data into categories, breaking down into units, synthesizing, organizing into patterns, choosing what is important and which will be studied, and make conclusions so that they are easily understood by themselves and others (Sugiono, 2010).

Descriptive analysis is used to explain various conditions and developments over time and the latest of the various indicators that will be needed later. Descriptions can later be displayed either in the form of tables, pictures / graphics, or general explanations making it easier for general readers to understand from the data and / or information provided in writing. Analysis can be done for centralizing statistics (including average, minimum, and maximum values), distribution (in the form of standard deviations, etc.), and the direction of development (positive, negative, or constant trends).

\section{2) The SWOT method}

The multi-dimensional SWOT analysis framework allows the use of this method widely in a variety of study contexts, especially in the study of development planning and formulation, as well as the development of competitive strategy models for Madrasah Tsanawiyah (MTs). In the context of the study model of developing a competitive Madrasah Tsanawiyah (MTs) strategy, the object of analysis is the Madrasah Tsanawiyah (MTs) from the Al Ghozali Foundation Islamic Boarding School Nganjuk Regency. Thus aspects related to and influencing the Madrasah Tsanawiyah competitive strategy development model (MTs) become the analysis variable. Because the SWOT method makes it possible to comprehensively review the aforementioned aspects, in this study the SWOT method is placed as a terminal of analysis. Where, the results of the analysis of quantitative and other qualitative models then become input or SWOT analysis material.

The strategic decision making process is generally always associated with the mission, objectives, strategies and policies of the Madrasah Tsanawiyah (MTs). Therefore, as a Model for developing a competitive Madrasah Tsanawiyah (MTs) strategy in conducting an analysis, it is necessary to pay attention to various aspects related to the factors that influence it. These factors can be broadly grouped into 4 categories called Strengths, Weakness, Opportunity and Threat, so they are known as Forward Analysis or SWOT Analysis. Even though it looks simple, the SWOT analysis can provide a complete identification of these Madrasah Tsanawiyah (MTs) factors.

SWOT analysis can simultaneously be used to evaluate internal and external factors at Madrasah Tsanawiyah (MTs) at once, so that the solution can then be sought. What are the strengths and weaknesses of Madrasah Tsanawiyah (MTs) will be identified in the IFAS (Internal Factor Analysis Summary) matrix, while the things that become opportunities and threats will be reflected in the EFAS (External Factor Analysis Summary) matrix. The combination of the two matrices through the SWOT diagram 
will reflect the position of Madrasah Tsanawiyah (MTs) known as positioning. Furthermore, this position will be used to identify strategic business planning carried out using the SWOT / TOWS matrix, GE-Mc Kensey, Product Life Cycle and so on.

\section{3) Stages of SWOT Analysis}

To conduct a SWOT analysis in outline, it must be carried out through three stages, namely:

a. Data collection stage.

Dalam tahap ini bukan hanya sekedar kegiatan mengumpulkan data, tetapi juga merupakan suatu kegiatan pengklasifikasian dan pra analisis. Umumnya data akan dikategorikan sebagai data internal dan eksternal. Data internal meliputi laporan keuangan Madrasah Tsanawiyah (MTs), laporan tentang sumber daya manusia, laporan kegiatan operasional dan pemasaran. Sedangkan data eksternal yang diperlukan antara lain meliputi analisis tentang pasar, pesaing, pemasok, pemerintah, serta kelompok yang mempunyai kepentingan tertentu. Data eksternal ini mempunyai hubungan yang sangat erat dengan stakeholder.

\section{b. Analysis phase}

The positive part of each $\mathrm{X}$ axis and $\mathrm{Y}$ axis will be occupied by Strength and Opportunity, while the negative portion of each $\mathrm{X}$ axis and $\mathrm{Y}$ axis will be occupied by Weaknesses and Threats. Plotting is done in the following ways:

- The total score that reflects the Opportunity of the EFAS matrix is plotted into the $\mathrm{Y}$ axis on the positive part.

- The total score that reflects the Threat of the EFAS matrix is plotted to the $\mathrm{Y}$ axis on the negative part
- The total score that reflects the Strength (Strength) of the IFAS matrix is plotted to the $\mathrm{X}$ axis on the positive part

- The same is done for the total score that reflects the Weaknesses of the IFAS matrix on the $\mathrm{X}$ axis on the negative part.

- Next do the positioning. The ideal position is a position that has a level of weakness and the level of threat that is close to zero. By knowing the last position, it is hoped that various strategies can be very useful for Madrasah Tsanawiyah (MTs).

- Calculate the area of each quadrant and then rank according to the highest area order. To provide a clearer picture of the SWOT Diagram, the following format will be presented as well as a full explanation.

\section{c. SWOT Matrix}

1) Internal Factor Analysis Strategy (IFAS) Matrix Analysis

IFAS matrix analysis summarizes and evaluates the main strengths and weaknesses in the functional areas of the business, and also provides a basis for identifying and evaluating the relationships between these areas. The IFAS table is compiled to formulate internal strategy factors. Identification of strengths and weaknesses obtained after conducting interviews with informants. From the results of the interview, strengths and weaknesses in the Madrasah Tsanawiyah (MTs) will be identified. These strengths and weaknesses are analyzed internally using the IFAS matrix. 
International Journal of Economics, Business and Accounting Research (IJEBAR)

Peer Reviewed - International Journal

Vol-3, Issue-2, 2019 (IJEBAR)

ISSN: 2454-1362, http://www.jurnal.stie-aas/ijebar

2) External Factor Analysis of

Strategy Analysis (EFAS))

The external factor

evaluation matrix (EFAS)

enables strategists to summarize

and evaluate economic, social,

cultural, demographic,

environmental, political,

government, legal, technological, and competitive information (David, 2006). Identification of opportunities and threats obtained after conducting interviews. From the results of the interview, opportunities and threats will be identified and analyzed externally using the EFAS matrix.

\section{RESEARCH RESULTS AND DISCUSSION}

\section{Description of Internal Conditions}

The following Internal Factor Analysis (IFAS) is described in the table of grading and weighting and assigning weights and ratings:

Table 1. Determination of IFAS Madrasah Tsanawiyah (MTs) Weight Value from Al GhozaliFoundation Islamic Boarding School Nganjuk Regency

\begin{tabular}{|c|c|c|c|c|c|c|}
\hline \multirow{2}{*}{ Internal strategic factors } & \multicolumn{4}{|c|}{ Answer } & \multirow{2}{*}{ Value } & \multirow[t]{2}{*}{ Weight } \\
\hline & $\mathrm{A}$ & $\mathrm{B}$ & $\mathrm{C}$ & $\mathrm{D}$ & & \\
\hline \multicolumn{7}{|l|}{ Strength } \\
\hline $\begin{array}{l}\text { 1. the number of students every year can be } \\
\text { said to increase, }\end{array}$ & & & $\sqrt{ }$ & & 3 & 0.096 \\
\hline 2. maintain the characteristics of salafiyah. & & & $\sqrt{ }$ & & 3 & 0.096 \\
\hline $\begin{array}{l}\text { 3. curriculum set by the ministry combined } \\
\text { with the salafiyah curriculum, }\end{array}$ & & & & $\sqrt{ }$ & 4 & 0.129 \\
\hline 4. good quality alumni & & & & $\sqrt{ }$ & 4 & 0.129 \\
\hline 5. expand location & & & & $\sqrt{ }$ & 4 & 0.129 \\
\hline \multicolumn{5}{|l|}{ Sub Total } & 18 & 0.58 \\
\hline \multicolumn{7}{|l|}{ Weakness } \\
\hline $\begin{array}{l}\text { 1. there are still teaching teachers who do not } \\
\text { fit their fields, }\end{array}$ & & & $\sqrt{ }$ & & 3 & 0.096 \\
\hline 2. facilities need improvement, & & & $\sqrt{ }$ & & 3 & 0.096 \\
\hline 3. the location needs to be expanded, & & & & $\sqrt{ }$ & 2 & 0.064 \\
\hline 4. promotion needs to be improved, & & & & $\sqrt{ }$ & 2 & 0.064 \\
\hline $\begin{array}{l}\text { 5. The teacher must meet academic } \\
\text { qualifications by increasing further study. }\end{array}$ & & & $\sqrt{ }$ & & 3 & 0.096 \\
\hline \multicolumn{5}{|l|}{ Sub Total } & 13 & 0.42 \\
\hline \multicolumn{5}{|l|}{ Total } & 31 & 1.0 \\
\hline
\end{tabular}

Explanation:

1. Weight $=\frac{\text { Rating }}{\text { total rating }} \times 1$

2. Weight $=\frac{\text { Rating }}{\text { total rating }} \times 1$

$$
\text { Weight }=\frac{4}{31} \times 1=0,129
$$

$$
\text { Weight }=\frac{3}{31} \times 1=0,096
$$




\section{Vol-3, Issue-2, 2019 (IJEBAR)}

ISSN: 2454-1362, http://www.jurnal.stie-aas/ijebar

3. Weight $=\frac{\text { Rating }}{\text { total rating }} x 1$

$$
\text { Weight }=\frac{2}{31} \times 1=0,064
$$

4. Weight $=\frac{\text { Rating }}{\text { total rating }} x 1$

$$
\text { Weight }=\frac{1}{31} \times 1=0,032
$$

Based on Table 1, there are four factors that are closely related to strength factors (strength), among them:

a. The first factor regarding the number of students each year can be said to increase, with an assessment of 3 and obtained a weight of 0.096 from the calculation that has been processed.

b. The second factor is about maintaining the characteristics of salafiyah with an assessment of 3 and a weighting of 0.096 is obtained from the calculated calculations.

c. The third factor regarding the curriculum set by the ministry is combined with the Salafiyah curriculum with an assessment of 4 and a weighting of 0.129 is obtained from the calculated calculations.

d. The fourth factor regarding the quality of alumni is good with a rating of 4 and a weighting of 0.129 is obtained from the calculated calculations.

e. The fifth factor is regarding location expansion by rating 4 and a weighting of 0.129 is obtained from the calculated calculations.

Based on Table 1. there are also five factors that are closely related to weaknesses, including: a. The first factor is that there are still teaching teachers who do not fit their fields with assessment 3 and obtained a weight of 0.096 from the calculated calculations.

b. The second factor regarding facilities needs to be improved by rating 3 and a weighting of 0.096 is obtained from the calculated calculations.

c. The third factor regarding location needs to be expanded, with a rating of 2 and a weighting of 0.064 obtained from the calculated calculations.

d. The fourth factor regarding promotion needs to be improved, with an assessment of 2 and a weighting of 0.064 is obtained from the calculated calculation.

e. The fifth factor regarding teachers must meet academic qualifications by increasing further studies, with an assessment of 3 and a weighting of 0.64 is obtained from the calculated calculations.

\section{Description of External Conditions}

The following Analysis of External Factors (EFAS) is given a table of grading and weighting and assigning weights and ratings: 
International Journal of Economics, Business and Accounting Research (IJEBAR)

Peer Reviewed - International Journal

Vol-3, Issue-2, 2019 (IJEBAR)

ISSN: 2454-1362, http://www.jurnal.stie-aas/ijebar

Table 2. Determination of EFAS Weight of Madrasah Tsanawiyah (MTs) from the Al Ghozali Foundation Islamic Boarding School Nganjuk Regency

\begin{tabular}{|c|c|c|c|c|c|c|}
\hline \multirow{2}{*}{ External strategic factors } & \multicolumn{4}{|c|}{ Answer } & \multirow[t]{2}{*}{ Value } & \multirow[t]{2}{*}{ Weight } \\
\hline & A & $\mathrm{B}$ & $\mathrm{C}$ & $\mathrm{D}$ & & \\
\hline \multicolumn{7}{|l|}{ Opportunities } \\
\hline $\begin{array}{l}\text { 1. the sons of the alumni themselves who go to } \\
\text { school and boarding school, }\end{array}$ & & & & $\sqrt{ }$ & 4 & 0.16 \\
\hline $\begin{array}{l}\text { 2. the number of new students and overall more } \\
\text { than any other cottage, }\end{array}$ & & & & $\sqrt{ }$ & 4 & 0.16 \\
\hline $\begin{array}{l}\text { 3. alumni as a reality brochure in the } \\
\text { community, }\end{array}$ & & & $\sqrt{ }$ & & 3 & 0.12 \\
\hline $\begin{array}{l}\text { 4. the addition of facilities can provide comfort } \\
\text { to students. }\end{array}$ & & & $\sqrt{ }$ & & 3 & 0.12 \\
\hline \multicolumn{5}{|l|}{ Sub Total } & 14 & 0.56 \\
\hline \multicolumn{7}{|l|}{ Threats } \\
\hline 1. many madrassas that offer convenience, & & & $\sqrt{ }$ & & 3 & 0.12 \\
\hline $\begin{array}{l}\text { 2. the influence of modern culture on the } \\
\text { madrasa is considered to be tacky, }\end{array}$ & & & $\sqrt{ }$ & & 3 & 0.12 \\
\hline 3. competitive ability that is still competitive, & & $\sqrt{ }$ & & & 2 & 0.08 \\
\hline $\begin{array}{l}\text { 4. the image that developed in the madrasa } \\
\text { graduate community was unable to fill } \\
\text { functional positions in government. }\end{array}$ & & & $\sqrt{ }$ & & 3 & 0.12 \\
\hline \multicolumn{5}{|l|}{ Sub Total } & 11 & 0.44 \\
\hline \multicolumn{5}{|l|}{ Total } & 25 & 1.0 \\
\hline
\end{tabular}

Explanation:

1. Weight $=\frac{\text { Rating }}{\text { total rating }} x 1$

2. Weight $=\frac{\text { Rating }}{\text { total rating }} x 1$

$$
\text { Weight }=\frac{4}{25} \times 1=0,16
$$

$$
\text { Weight }=\frac{3}{25} \times 1=0,12
$$

3. Weight $=\frac{\text { Rating }}{\text { total rating }} x 1$

$$
\text { Weight }=\frac{2}{25} \times 1=0,08
$$

4. Weight $=\frac{\text { Rating }}{\text { total rating }} \times 1$

$$
\text { Weight }=\frac{1}{25} x 1=0,04
$$


Based on Table 2, there are seven factors that are closely related to opportunity factors, including:

a. The first factor concerns the children of the alumni themselves who go to school and boarding school, with an assessment of 4 and a weighting of 0.16 is obtained from the calculated calculation.

b. The second factor is the number of new students and the total number of students compared to other huts, with an assessment of 4 and a weighting of 0.12 is obtained from the calculated calculations.

c. The third factor regarding alumni as a reality brochure in the community, with a rating of 3 and obtained a weight of 0.12 from the calculation that has been processed.

d. The fourth factor regarding the addition of facilities can provide comfort to students with an assessment of 3 and obtained a weight of 0.12 from the calculation that has been processed.

Based on Table 4.6, there are also four factors that are closely related to threat factors (Treath), including:

a. The first factor is the number of similar madrasas that offer convenience, with a rating of 3 and a weighting of 0.12 from the calculated calculation.

b. The second factor regarding the influence of modern madrasa culture is considered tacky, with an assessment of 3 and a weighting of 0.12 is obtained from the calculated calculations.

c. The third factor is the competitive ability that is still competitive, with a rating of 2 and a weighting of 0.08 is obtained from the calculated calculation. d. The fourth factor regarding the image that develops in the madrasa graduate community is not able to fill functional positions in government, with a rating of 3 and a weighting of 0.12 is obtained from the calculated calculations.

3. SWOT Analysis Model of developing competitive Madrasah Tsanawiyah (MTs) strategies

In this study, the SWOT analysis is used to find out what strategies should be implemented by the Madrasah Tsanawiyah (MTs) of the Al Ghozali Foundation Islamic Boarding School in Nganjuk Regency. Take advantage of market opportunities through analysis of internal and external factors that influence the efforts of Madrasah Tsanawiyah (MTs) from the Al Ghozali Foundation Islamic Boarding School Nganjuk Regency. SWOT analysis involves internal factors, namely the strengths and weaknesses of Madrasah Tsanawiyah (MTs) from the Al Ghozali Foundation Islamic Boarding School Nganjuk Regency and external factors, namely the opportunities and threats faced by the Madrasah Tsanawiyah (MTs) of the Al Ghozali Foundation Islamic Boarding School Nganjuk Regency.

From the results of determining the value of weights on internal and external factors Madrasah Tsanawiyah (MTs) from Al Ghozali Foundation Islamic Boarding School Nganjuk Regency in table 1 and table 2 the next step is to calculate the weight and rating values, as listed in tables 3 and table 4 the following: 
International Journal of Economics, Business and Accounting Research (IJEBAR)

Peer Reviewed - International Journal

Vol-3, Issue-2, 2019 (IJEBAR)

ISSN: 2454-1362, http://www.jurnal.stie-aas/ijebar

Table 3. Calculation of IFAS in Madrasah Tsanawiyah (MTs) from Pondok Pesantren Al Ghozali Foundation Nganjuk Regency

\begin{tabular}{|l|c|c|c|}
\hline \multicolumn{1}{|c|}{ Internal strategic factors } & Weight & Rating & $\begin{array}{c}\text { Weight } x \\
\text { rating }\end{array}$ \\
\hline Strength & 0.096 & 3 & 0.288 \\
\hline $\begin{array}{l}\text { 1. The number of students every year can be } \\
\text { said to increase. }\end{array}$ & 0.096 & 3 & 0.288 \\
\hline 2. Maintain salafiyah characteristics. & 0.129 & 4 & 0.516 \\
\hline $\begin{array}{l}\text { 3. The curriculum established by the ministry } \\
\text { is combined with the salafiyah curriculum. }\end{array}$ & 0.129 & 4 & 0.516 \\
\hline 4. Good quality alumni & 0.129 & 4 & 0.516 \\
\hline 5. Expand location. & 0.58 & 18 & 2.124 \\
\hline Sub Total & & & \\
\hline Weaknesses & 0.096 & 3 & 0.288 \\
\hline $\begin{array}{l}\text { 1. there are still teaching teachers who do not } \\
\text { fit their fields, }\end{array}$ & 0.096 & 3 & 0.288 \\
\hline 2. facilities need improvement, & 0.064 & 2 & 0.128 \\
\hline 3. the location needs to be expanded, & 0.064 & 2 & 0.128 \\
\hline 4. promotion needs to be improved, & 0.096 & 3 & 0.288 \\
\hline $\begin{array}{l}\text { 5. The teacher must meet academic } \\
\text { qualifications by increasing further study. }\end{array}$ & \multicolumn{1}{|l}{} \\
\hline Sub total & 0.42 & 13 & 1.12 \\
\hline
\end{tabular}

Whereas the calculation of external factors (EFAS) is arranged in the same way as by compiling an internal factor matrix (IFAS) but strengths are replaced by opportunities, whereas weaknesses are replaced by threats. The EFAS calculation results are shown in the following table:

Table 4. Calculation of EFAS in Madrasah Tsanawiyah (MTs) from Al Ghozali Foundation Islamic Boarding School Nganjuk Regency

\begin{tabular}{|l|c|c|c|}
\hline \multicolumn{1}{|c|}{ External strategic factors } & Weight & Rating & $\begin{array}{c}\text { Weight } \\
\text { x rating }\end{array}$ \\
\hline Opportunities & 4 & 0.16 & 0.64 \\
\hline $\begin{array}{l}\text { 1. the sons of the alumni themselves who go to school } \\
\text { and boarding school, }\end{array}$ & 4 & 0.16 & 0.64 \\
\hline $\begin{array}{l}\text { 2. the number of new students and overall more than } \\
\text { any other cottage, }\end{array}$ & 3 & 0.12 & 0.36 \\
\hline 3. alumni as a reality brochure in the community, & 3 & 0.12 & 0.36 \\
\hline $\begin{array}{l}\text { 4. the addition of facilities can provide comfort to } \\
\text { students. }\end{array}$ & 14 & & 2 \\
\hline $\begin{array}{l}\text { Sub Total } \\
\text { Threats }\end{array}$ & 3 & 0.12 & 0.36 \\
\hline $\begin{array}{l}\text { 1. The number of similar madrassas that offer } \\
\text { convenience, }\end{array}$ & & & \\
\hline
\end{tabular}


ISSN: 2454-1362, http://www.jurnal.stie-aas/ijebar

\begin{tabular}{|l|c|c|c|}
\hline \multicolumn{1}{|c|}{ External strategic factors } & Weight & Rating & $\begin{array}{c}\text { Weight } \\
\text { x rating }\end{array}$ \\
\hline $\begin{array}{l}\text { 2. the influence of modern culture on the madrasa is } \\
\text { considered to be tacky, }\end{array}$ & 3 & 0.12 & 0.36 \\
\hline 3. competitive ability that is still competitive, & 2 & 0.08 & 0.24 \\
\hline $\begin{array}{l}\text { 4. the image that developed in the madrasa graduate } \\
\text { community was unable to fill functional positions in } \\
\text { government. }\end{array}$ & 3 & 0.12 & 0.36 \\
\hline Sub total & 11 & & 1.32 \\
\hline
\end{tabular}

Based on table 3 above the strength factors have a score of 2.124 while the weakness factors have a score of 1.12. Means Madrasah Tsanawiyah (MTs) from Al Ghozali Foundation Islamic Boarding School Nganjuk Regency has a higher weakness compared to the strength factor in determining the Model of developing competitive Madrasah Tsanawiyah (MTs) competitiveness. Furthermore, in table 4 above, opportunity factors have a score of 2 and threats have a score of 1.32. The score shows that the competitive strategy development model of Madrasah Tsanawiyah (MTs) Madrasah Tsanawiyah (MTs) from the Al Ghozali Foundation Islamic Boarding School Nganjuk Regency has the opportunity and strength so that it can take full advantage of opportunities so that it can implement strategies that support aggressive growth policies.

\section{Development Strategy}

After knowing the SWOT matrix which is obtained combines the internal factors in developing the competitive strategy of Madrasah Tsanawiyah (MTs) from the Al Ghozali Foundation boarding school Nganjuk Regency with external factors in realizing the development of the Tsanawiyah Madrasah Competitive Strategy (MTs) from the $\mathrm{Al}$
Ghozali Foundation Islamic Boarding School Nganjuk Regency. To find out the conditions of achieving the development of a competitive Madrasah Tsanawiyah (MTs) strategy from the Al Ghozali Foundation Islamic Boarding School in Nganjuk Regency, it will be illustrated in the SWOT analysis diagram from the IFAS and EFAS weighting results. This is to find out the right strategy for Madrasah Tsanawiyah (MTs) to be able to develop competitive strategies for Madrasah Tsanawiyah (MTs) from the Al Ghozali Foundation Islamic Boarding School Nganjuk Regency. Once it is found in which quadrant, the Madrasah Tsanawiyah (MTs) will be able to find out the strategy to be implemented into seen in Figure 1 SWOT analysis diagram.

From the results of the arrangement of internal and external factors above, it produces a series of scores as follows:
a. Strenghts
$=2.124$
b. Weaknesses
$=1.12$
c. Opportunities
$=2$
d. Threats
$=1.32$

Based on the results of data processing on the internal evaluation matrix and the external evaluation matrix obtained the value of each of these matrices, which then becomes input for quadrant analysis. 
International Journal of Economics, Business and Accounting Research (IJEBAR)

Peer Reviewed - International Journal

Vol-3, Issue-2, 2019 (IJEBAR)

ISSN: 2454-1362, http://www.jurnal.stie-aas/ijebar

$\begin{array}{ll}\text { Internal Evaluation Matrix Value } & =\text { Total Strength }- \text { Total Weakness } \\ & =2.124-1.12 \\ & =1.004 \\ & \\ \text { Nilai Matriks Evaluasi Eksternal } & =\text { Total Peluang }- \text { Total Ancaman } \\ & =2-1.32 \\ & =0.68\end{array}$

From this set of scores, an IFAS and EFAS Score Score Recapitulation table can be prepared as follows:

Table 5. Recapitulation of IFAS and EFAS Score

\begin{tabular}{|c|c|c|}
\hline Internal Score & Eksternal Score & Choice of Strategy \\
\hline $\mathrm{S}>\mathrm{W}(+)$ & $\mathrm{O}>\mathrm{T}(+)$ & Growth \\
1.004 & 0.68 & Survival \\
\hline $\mathrm{S}<\mathrm{W}(-)$ & $\mathrm{O}<\mathrm{T}(-)$ & Diversification \\
\hline $\mathrm{S}>\mathrm{W}(+)$ & $\mathrm{O}<\mathrm{T}(-)$ & Stability \\
\hline $\mathrm{S}>\mathrm{W}(-)$ & $\mathrm{O}>\mathrm{T}(+)$ & \\
\hline
\end{tabular}

To determine the choice of strategies that are more specific than the values obtained are included in the strategy choice diagram, because the results from table 4.8 show that the existing score leads to the next choice of strategy growth determines more specific growth strategies.

Position of competitive strategy development model in Quadrant I. This position illustrates that the situation is advantageous because the madrasa has opportunities and strengths so that it can take full advantage of opportunities so as to be able to implement strategies that support aggressive growth policies. The quadrant coordinate position of the competitive strategy development model can be presented in Figure 1. below:

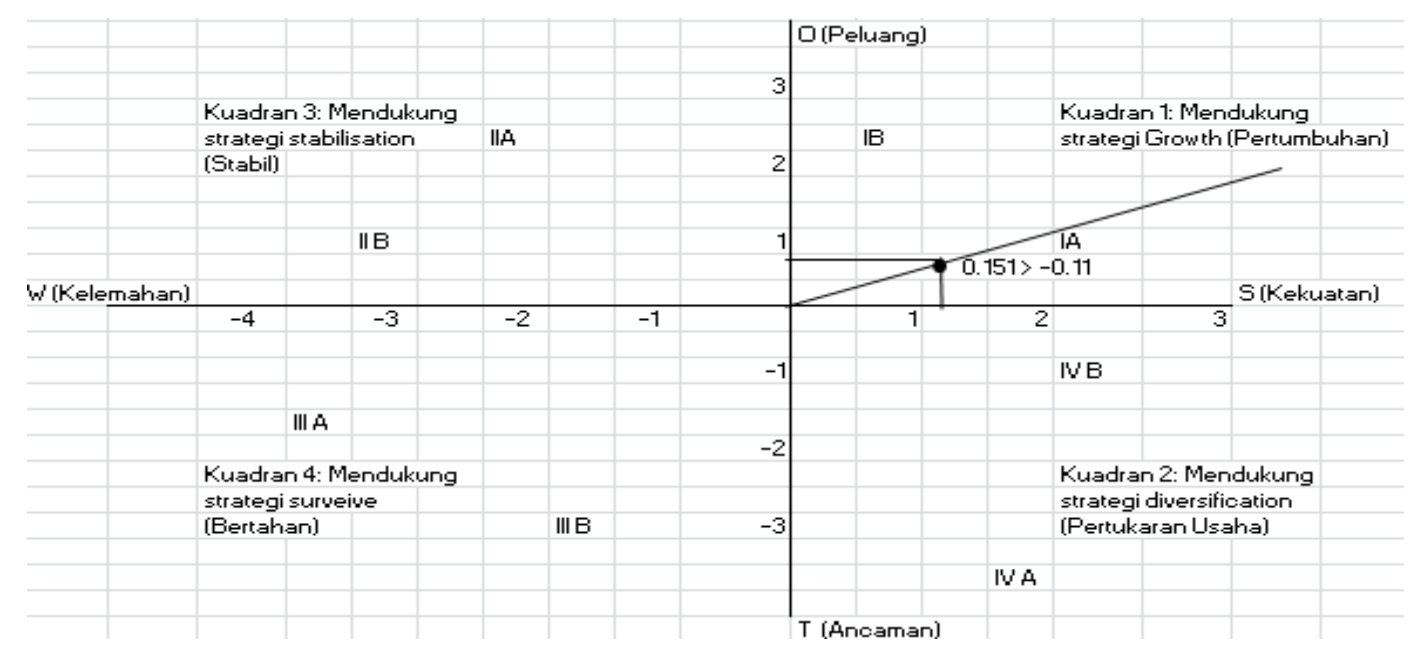

Figure 1. Quadrant Analysis Results 
ISSN: 2454-1362, http://www.jurnal.stie-aas/ijebar

Furthermore, the SWOT matrix will be made as follows:

Table 6. SWOT Matrix Analysis

\begin{tabular}{|c|c|c|}
\hline & Strenght $(\mathrm{S})$ & Weakness (W) \\
\hline IFASEEAS & $\begin{array}{l}\text { 1. The number of } \\
\text { students every year } \\
\text { can be said to } \\
\text { increase. } \\
\text { 2. Maintain salafiyah } \\
\text { characteristics. } \\
\text { 3. The curriculum } \\
\text { established by the } \\
\text { ministry is } \\
\text { combined with the } \\
\text { salafiyah } \\
\text { curriculum. } \\
\text { Good quality } \\
\text { alumni } \\
\text { 5xpand location. }\end{array}$ & $\begin{array}{l}\text { 1. there are still teaching teachers } \\
\text { who do not fit their fields, } \\
\text { 2. facilities need improvement, } \\
\text { 3. the location needs to be expanded, } \\
\text { 4. promotion needs to be improved, } \\
\text { 5. The teacher must meet academic } \\
\text { qualifications by increasing further } \\
\text { study. }\end{array}$ \\
\hline Opportunities (O) & Strategy S-O & Strategy W-O \\
\hline $\begin{array}{l}\text { 1. the sons of the alumni } \\
\text { themselves who go to } \\
\text { school and boarding } \\
\text { school, } \\
\text { 2. the number of new } \\
\text { students and overall } \\
\text { more than any other } \\
\text { cottage, } \\
\text { 3. alumni as a reality } \\
\text { brochure in the } \\
\text { community, } \\
\text { 4. the addition of facilities } \\
\text { can provide comfort to } \\
\text { students. }\end{array}$ & $\begin{array}{l}\text { 1. The number of } \\
\text { students that } \\
\text { increase each year } \\
\text { is due to the } \\
\text { children of the } \\
\text { alumni who go to } \\
\text { school and boarding } \\
\text { school } \\
\text { 2urriculum } \\
\text { determined by the } \\
\text { ministry combined } \\
\text { with the Salafiyah } \\
\text { curriculum, so that } \\
\text { the number of new } \\
\text { students is more } \\
\text { than the total } \\
\text { number of students } \\
\text { before. } \\
\text { Good quality } \\
\text { alumni can be seen } \\
\text { from existing } \\
\text { alumni in the } \\
\text { community } \\
\text { Adding locations } \\
\text { can provide comfort } \\
\text { for students. }\end{array}$ & $\begin{array}{l}\text { 1. Teachers who teach teach not } \\
\text { according to their fields to } \\
\text { immediately make improvements } \\
\text { given the increasing number of } \\
\text { alumni. } \\
\text { 2. Facilities need to be updated due to } \\
\text { the increasing number of new } \\
\text { students. } \\
\text { 3. Promotion needs to be increased by } \\
\text { increasing the number of alumni } \\
\text { scattered in the community. }\end{array}$ \\
\hline Threats (T) & Strategi S-T & Strategi W-T \\
\hline 1. many madrassas that & $\begin{array}{l}\text { 1. The growing } \\
\text { number of }\end{array}$ & $\begin{array}{l}\text { 1. Madrasas must immediately } \\
\text { improve teacher qualifications, }\end{array}$ \\
\hline
\end{tabular}


ISSN: 2454-1362, http://www.jurnal.stie-aas/ijebar

\begin{tabular}{|c|c|c|}
\hline $\begin{array}{l}\text { offer convenience, } \\
\text { 2. the influence of } \\
\text { modern culture on the } \\
\text { madrasa is considered } \\
\text { to be tacky, } \\
\text { 3. competitive ability } \\
\text { that is still } \\
\text { competitive, } \\
\text { 4. the image that } \\
\text { developed in the } \\
\text { madrasa graduate } \\
\text { community was } \\
\text { unable to fill } \\
\text { functional positions in } \\
\text { government. }\end{array}$ & $\begin{array}{l}\text { students does not } \\
\text { affect the number } \\
\text { of other madrasas. } \\
\text { 2. Maintaining the } \\
\text { characteristics of } \\
\text { salafiyah, is not a } \\
\text { plebeian. } \\
\text { 3. curriculum set by } \\
\text { the ministry } \\
\text { combined with the } \\
\text { salafiyah } \\
\text { curriculum } \\
\text { becomes the } \\
\text { ability to compete }\end{array}$ & $\begin{array}{l}\text { given the large number of } \\
\text { madrasas that offer convenience. } \\
\text { 2. Increased promotion will increase } \\
\text { the ability to compete between } \\
\text { madrassas. } \\
\text { 3. Madrasa quality graduates can } \\
\text { reduce the negative image that } \\
\text { develops in the community. }\end{array}$ \\
\hline
\end{tabular}

Based on the external internal matrix above CV MatolDjaya is on the value of the IFAS matrix is Strength (Strenghts) is 2.124 and from the EFAS matrix is opportunity (Opportunity) is value 2, This means that the recommended strategy is the Strength strategy (Strenghts) and Opportunity (opportunity) or known as SO strategy, that is, use power to overcome opportunities. Analysis of the strategy carried out in the development model of the competitive growth strategy is the IE Matrix strategy and the SWOT diagram is to show Quadrant I which means the situation is favorable because the madrasa has opportunities and strengths so that it can take full advantage of opportunities so as to be able to implement strategies that support aggressive growth policies.

Alternative models of developing competitive strategies in Madrasah Tsanawiyah (MTs) that can be taken are:

1) The number of students that increase each year is due to the children of the alumni who go to school and boarding school

2) Curriculum determined by the ministry combined with the Salafiyah curriculum, so that the number of new students is more than the total number of students before.
3) Good quality alumni can be seen from existing alumni in the community

4) Adding locations can provide comfort for students.

Based on the calculation of the SWOT analysis method in Madrasah Tsanawiyah (MTs) from the Al Ghozali Foundation Islamic Boarding School Nganjukdari District results of analysis of internal and external factors, means that the strength of the Tsanawiyah Madrasah (MTs) is superior compared to opportunities, while the environment currently faced is more equal to the threat. Therefore, Madrasah Tsanawiyah (MTs) have the ability to turn potential into better performance and performance. So that the right strategic direction to be implemented is to increase and enlarge the role of Madrasah Tsanawiyah (MTs) in various activities in accordance with their capabilities as well as to expand their roles and take advantage of various opportunities.

The policy direction is the basis for a stable strategy shown by Quadrant I, which means the situation is favorable because the madrasa has opportunities and strengths so that it can take full advantage of opportunities so as to be able to implement strategies that support aggressive growth policies. That is, in future development, Madrasah Tsanawiyah 
(MTs) can use an aggressive growth strategy that is carried out in stages according to priority scale. And the strategy is supported by the number of students who are increasing every year due to the children of the alumni who go to school and boarding school, the curriculum set by the ministry combined with the Salafiyah curriculum, so that the number of new students is more than the total number of students before, good quality alumni can be seen from existing alumni in the community and the addition of locations can provide comfort to students can improve the development of aggressive competitive strategies in Madrasah Tsanawiyah (MTs).

\section{CONCLUSION AND RECOMMENDATION \\ Conclusion}

The competitive strategy is carried out by: a) greater demand for good communication with the head and foundation for the advancement of madrasas, increasing education staff and infrastructure, b) Bidding by preparing and managing students properly, integrating the Learning curriculum of the Ministry of religion and the salafiyah curriculum. c) Marketing by combining learning of the Ministry of religion curriculum and the Salafiyah curriculum, costs allocated according to the budget, alumni are real life brochures and through websites and competitions lined up, and access to madrasas is very easy and extends locations. Based on internal and external analysis above, in a stable growth strategy condition which means that the situation is favorable because boarding schools have opportunities and strengths, boarding schools can take full advantage of opportunities so as to be able to implement strategies that support aggressive growth policies.

\section{Recommendation}

1. For Madrasah Tsanawiyah (MTs) from Al Ghozali Foundation Islamic Boarding School Nganjuk Regency
The results of this study are expected to be information and study material in formulating competitive strategies and marketing of schools, especially in Madrasah Tsanawiyah (MTs) from the Al Ghozali Foundation Islamic Boarding School Nganjuk Regency in order to be able to maintain their existence.

2. For Further Researchers

The results of this study, can be used as a reference for further education studies. In addition, the results of this study are expected to be used as reference material for subsequent research related to the development of competitive strategies and marketing strategies of environmentally-oriented private schools in particular. Especially for researchers who take the same title and theme to be used as references and additional material in their studies, with the hope, more specific and accurate data can be obtained and can be useful to add data and knowledge in the study of economics. The results of this study are also expected to be an inspiration and motivation for the development of competitive strategy development models.

\section{REFERENCES}

Best, Rogers. 2000. Market Based Management. Strategies for Growing, Customer Value and Profitability. Upper Saddle River New Jersey: Prentice Hall: 205-230.

Budi, A P. 2013. Manajemen Marketing Perhotelan. Edisi 1. Yogyakarta: Andi.

Bungin, P. D. 2007. Penelitian Kualitatif: Komunikasi, Ekonomi, Kebijakan Publik, dan Ilmu Sosial Lainnya. Jakarta: Kencana Prenada Media Group. 
International Journal of Economics, Business and Accounting Research (IJEBAR)

Peer Reviewed - International Journal

Vol-3, Issue-2, 2019 (IJEBAR)

ISSN: 2454-1362, http://www.jurnal.stie-aas/ijebar

David, F.R. 2008. Manajemen Strategis:

Konsep, Edisi 10. Jakarta: Salemba.

Julita \& Sari, S. 2015. Strategi Generik Porter Bagi UMKM dalam Menghadapi Masyarakat Ekonomi ASEAN (MEA) (Studi Kasus: Pada UMKM di Kabupaten Deli Serdang). SNEMA Fakultas Ekonomi Universitas Padang. ISBN: 978-60217129-5-5. pp 132-142.

Kotler, P \& Gary A. 1997. Dasar-Dasar Pemasaran. Edisi Indonesia. Alih Bahasa Alexander Sindoro. Jilid 1. Jakarta: Perinhallindo.

Kotler, Philip. 2006. Manajemen Pemasaran. Edisi 11. Jakarta: PT. Indek. Hal. 16.

Mankiw, Gregory N. 2004. Pengantar Ekonomi Mikro. Jakarta: Salemba Empat.

Payne, A. 2001. The Essence of Service Marketing Pemasaran Jasa. Diterjemahkan oleh Fandy Tjiptono. Yogyakarta: Andy.

Porter. 2007. Strategy bersaing (Competitive Strategy): Teknik Menganalisis Industri dan Pesaing. Tangerang: Karisma Publishing Group

Purwanto, N. A. 2011. Strategi Bersaing Dalam Bisnis Pendidikan, Jurnal Manajemen Pendidikan, Vol. 7, No. 1.

Rahim, Husni. 2001. Arah Baru Pendidikan Islam di Indonesia. Jakarta: Logos

Silalahi, U. 2009. Metode Penelitian Sosial. Bandung: PT Refika Aditama.

Sugiyono. 2012. Metode Penelitian Kuantitatif dan Kualitatif. Bandung: CV. Alfabeta.

Swastha dan Irawan. 1990. Manajemen Pemasaran Modern. Yogyakarta: Liberty.

Wijaya, D. 2008. Pemasaran Jasa Pendidikan Sebagai Upaya untuk Meningkatkan Daya Saing Sekolah. Jurnal Pendidikan Penabur. Vol. 11 No. 7. 